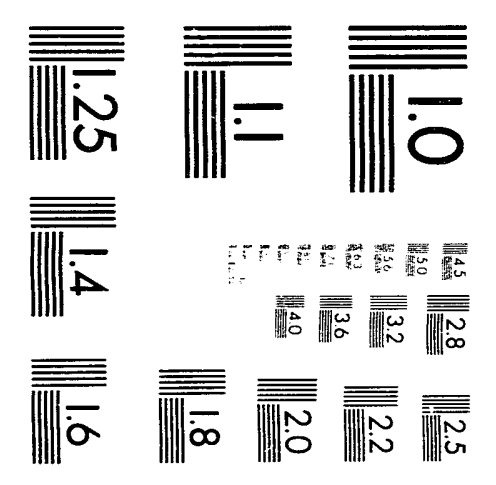



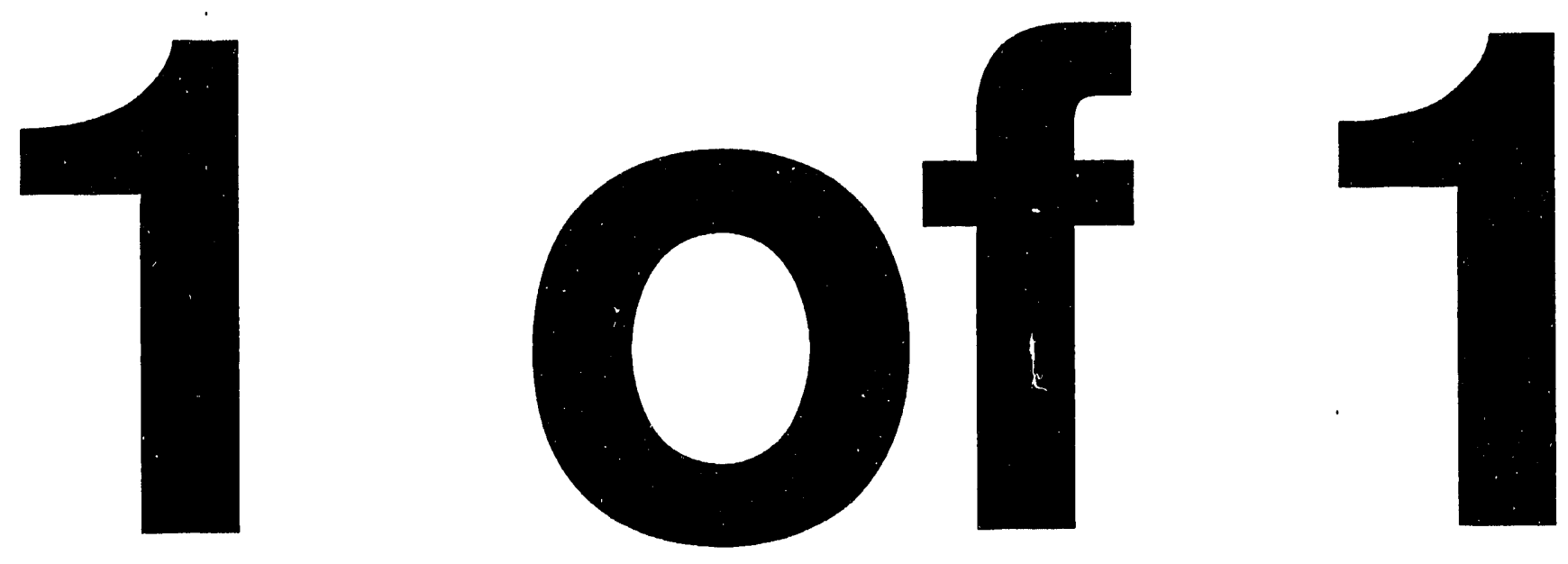
DATE: September 13, 1993

REPLY TO

ATTN OF:

The Inspector General

SUBNECT:

INFORMATION: Report on the "Inspection of the Policies and Procedures for the Designation and Continuation of the Department of Energy's Federally Funded Research and Development Centers"

TO: The Secretary

\section{BACKGROUND :}

We conducted an inspection of the Department's designation and continuation of its Federally Funded Research and Development Centers. The purpose of the inspection was to review and describe the Department's history of designating its research laboratories as Federally Funded Research and Development Centers, and to review the Department's compliance with the Office of Federal Procurement Policy's requirements for establishing and renewing Federally Funded Research and Development Centers.

\section{DISCUSSION :}

The Office of Federal Procurement Policy established Federally Funded Research and Development Center policies and procedures in 1984. The Department currently has nineteen of these centers operated under nineteen management and operating contracts - eighteen of which were extended without competition between 1988 and 1993 .

The Department uses but does not need the Federally Funded Research and Development Center designation to noncompetitively extend its management and operating contracts - - the Atomic Energy Act already provides this authority. Thus, when the Federally Funded Research and Development Center designation of a laboratory is discontinued, there are few if any impacts on the laboratory's existence, operating contract, mission, or work assignments.

In 1984, Departmental officials advised the Office of Federal Procurement Policy that the Department would use its management and operating contract procedures to satisfy the requirements of the Federally Funded Research and Development Center policies and procedures. 
We found that in implementing the management and operating contract procedures, Departmental officials did not appear to comply with all office of Federal Procurement Policy requirements for Federally Funded Research and Development Centers. For example, Departmental officials: 1) did not appear to review alternative sources for the work performed at their Centers prior to establishing or renewing them; 2 ) did not appear to have procedures in place to ensure that their Centers were operated cost effectively; and 3 ) did not document their decisions to continue the Federally Funded Research and Development Center designation for their laboratories.

The Department has already initiated actions which should address findings one and two. For example, at your direction Departmental officials recently established a task force to recommend ways to improve management of the Department's management and operating contracts - - including those that operate the Department's Federally Funded Research and Development Centers. Also, an Office of Federal Procurement Policy official stated that his office is considering issuing additional guidance for these Centers. As a result, this report does not include recommendations regarding findings one and two.

Regarding the third finding, we recommended that Departmental officials document their decisions to continue the Federally Funded Research and Development Center designation of their laboratories.

In commenting on this report, the Acting Deputy Assistant Secretary for Procurement and Assistance Management concurred with the recommendation stating that if the focus of our recommendation is on the Federally Funded Research and Development Center designation and not the validation of a laboratory's mission, the Procurement Executive can require that this subject be addressed by the management and operating contract extend/compete boards and an appropriate statement be included in the files.

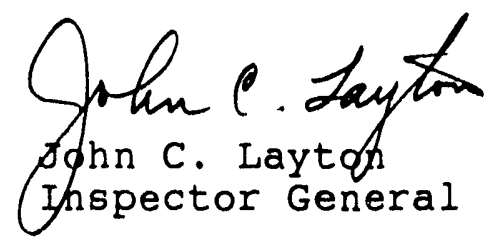

Attachment 
U. S. DEPARTMENT OF ENERGY

OFFICE OF INSPECTOR GENERAL

\author{
REPORT ON THE INSPECTION OF THE \\ POLICIES AND PROCEDURES FOR THE DESIGNATION \\ AND CONTINUATION OF THE DEPARTMENT OF ENERGY'S \\ FEDERALLY FUNDED \\ RESEARCH AND DEVELOPMENT CENTERS
}

REPORT NO.: DOE/IG-0334

DATE ISSUED: September 13, 1993
OFFICE OF INSPECTIONS

WASHINGTON, D.C. 20585 
TABLE OF CONTENTS

I. INTRODUCTION, PURPOSE, SCOPE AND METHODOLOGY..... 1

II. SUMMARY RESULTS OF INSPECTION............... 2

III. BACKGROUND.......................... 4

IV. RESULTS OF INSPECTION.................. 7

V. APPENDIXES :

A. Department of Energy's Federally Funded Research and Development Centers

B. 1980 Department of Energy Point Paper on Federally Funded Research and Development Centers

C. Federal Acquisition Regulation 17.605 Award, renewal, and extension.

D. Department of Energy Acquisition Regulation 970.0001 - Renewal of management and Operating contracts.

E. Section $6 . j$. of the office of Federal Procurement Policy Letter 84-1 


\author{
Inspection of the \\ Polices and Procedures for the \\ Designation and Continuation of the \\ Department of Energy's \\ Federally Funded \\ Research and Development Centers
}

\begin{abstract}
I. INTRODUCTION, PURPOSE, SCOPE AND METHODOLOGY
In 1984, the Office of Federal Procurement Policy (OFPP) issued policy and procedures for Federal agencies to use in establishing and periodically renewing research facilities as Federally Funded Research and Development Centers (FFRDCs). FFRDCs perform research and are at least 70 percent funded by the Government and may also be owned by the Government. Also, FFRDCs are operated or managed, under a long-term agreement, by either a university or consortium of universities, other non-profit organization, an autonomous industrial firm, or separate operating unit of a company. Seven Federal agencies currently sponsor 38 FFRDCs, incliding 19 at the Department of Energy (DOE). The OFPP policy requires the National science Foundation to maintain a listing of FFRDCs sponsored by Federal agencies.
\end{abstract}

By a memorandum dated september 16, 1992, OFPP requested that the DOE, Office of Inspector General, conduct a "special" audit of the nature and adequacy of DOE's FFRDC sole-source renegotiation justifications developed since 1985. The OFPP request was based on a July 8, 1992 Senate subcomittee on Oversight of Government Management report entitled "Inadequate Federal Oversight of Federally Funded Research and Development centers", which detailed the need for strengthened federal controls over FFRDCs.

The Office of Inspector General initiated an inspection in order to review and describe the Department's history of designating its research laboratories as FFRDCs, and to review the Department's compliance with the OFPP policy and procedures for establishing and renewing its FFRDCs. We also reviewed DOE's sole-source renegotiation justifications to non-competitively extend its M\&O contractors that manage DOE's FFRDCs since september 30,1984 .

In conducting the inspection, we reviewed Federal laws and regulations, DOE policies and procedures, and other requirements 
related to FFRDCs. We interviewed DOE officials in the DOE Oak Ridge and Savannah River Operations Offices, Headquarters '

Office of Procurement, Assistance and Program Management, office of Energy Research, and the Office of General Counsel.

Furthermore, we reviewed the office of Procurement Policy files and the contract files related to the Department's establishment and renewal of its laboratories as FFRDCs. Finally, we reviewed other reports and documentation from outside sources, including GAO reports and a report from the Commission on Government Procurement. This inspection was conducted in accordance with Quality Standards for Inspections issued by the President's Council on Integrity and Efficiency.

\section{SUMMARY RESULTS OF INSPECTION}

We found that in 1984,20 of DOE's existing laboratories, operated by management and operating (M\&O) contractors, were designated as FFRDCs in response to the OFPP policy letter. Many of DOE's laboratories have existed since the 1940's or 1950 's and were established under DOE's predecessor agencies' authority. Historically, the M\&O contracts to operate DOE laboratories were typically extended noncompetitively using authorities based on the Atomic Energy Act of 1954 as amended. Currently, decisions to noncompetitively extend these contracts cite the Atomic Energy Act as well as the FFRDC provision of the Competition in Contracting Act. DOE officials do not need the FFRDC designation to noncompetitively extend their M\&O contracts - the Atomic Energy Act provides this authority and it is recognized in the Federal Acquisition Regulation (FAR). Thus, when FFRDC designation is discontinued for a DOE laboratory, there are few impacts. For example, the discontinuation of FFRDC designation in 1992 for the Bettis and Knolls Atomic Power Laboratories did not impact these laboratories' existence, contracts, mission, or work assignments.

Although DOE's laboratories were designated as FFRDCs, DOE had objected to the OFPP developing a single FFRDC policy. DOE had written to OFPP in 1984 that they would use their existing M\&O contract procedures to satisfy the requirements of the FFRDC policy. We did not find evidence that OFPP disagreed with this position. In fact, the OFPP policy letter recognized M\&O contract procedures by including a statement that

".... i] mplementation [of FFRDC policy in the FAR] will be written so as to be compatible with the requirements.... of FAR 17.6 'Management and Operating Contracts." " 
We reviewed how DOE officials designated and renewed FFRDCs and found that they did not appear to comply with all OFPP FFRDC procedures. For example, we found that DOE officials: 1) did not appear to review alternative sources for the work performed at FFRDC laboratories prior to establishing or renewing them; 2) did not appear to have procedures in place to ensure that their FFRDCs are operated cost effectively; and 3 ) did not document the decision to continue the FFRDC designation for their laboratories.

Regarding the first finding, the Director, Office of Management, Office of Energy Research did not agree that the OFPP Policy Letter required a periodic evaluation of alternatives to contracting with an FFRDC for meeting an agency's needs. He stated "In our opinion, what is required to be reviewed is the contractor that operates the FFRDC."

An OFPP official told us that the term "alternative sources" in the 1984 OFPP policy letter is in reference to the FFRDC, but that consideration of alternative contractors to operate FFRDCs may be viewed as meeting OFPP policy in the future.

The Associate Director, Procurement, Assistance and Property stated that existing Departmental procedures for establishing FFRDCs include an assessment of whether alternatives to FFRDCs exist. He also stated that the laboratories' long term institutional budget plans are a continuing assessment of whether an FFRDC laboratory mission is still necessary. We noted that for the two FFRDCs DOE has established since 1984, there were Commerce Business Daily and Federal Register notices -which might be viewed as a consideration of alternative sources. We did not find any other written evidence of a consideration of alternatives to the FFRDCs.

Regarding the second finding, we noted that Departmental officials have recognjued the need to improve their management of contractors that operate DOE's laboratories-including DOE's FFRDCs. For example, Departmental officials stated in their 1992 Federal Managers' Financial Integrity Act letter to the former President, that the business management practices of the Department and its contractors need improvement to ensure programs and projects are completed within costs and estaolished schedules. In addition, the secretary stated in her May 26, 1993 testimony before the Subcommittee on Oversight and Investigations of the House Committee on Energy and Commerce, that DOE is not adequately in control of its contractors and as a result the contractors are not sufficiently accountable to the 
Department. The secretary announced in her testimony initiatives to improve contract management practices, to include efforts to increase cost control measures.

We have not included recommendations in this report regarding findings one and two, for several reasons. First, the secretary recently established a task force to recommend ways to improve management of the Department's M\&O contracts-including those that operate DOE's FFRDCs. Second, an OFPP official stated that OFPP is considering issuing additional guidance for FFRDCs. Third, as noted by the Associate Director for Procurement, Assistance, and property, in his comments on a draft of this report, laboratory missions and structures are being examined by the Congress and the Department in light of the "profound changes in the economic and military realities of the modern world."

Regarding the third finding, if DOE is going to continue to designate its laboratories as FFRDCs, we recommend that Departmental officials document their decisions to extend the laboratories' FFRDC designations at the time they extend or award the M\&O contracts to operate the laboratories. The Acting Deputy Assistant Secretary for Procurement and Assistance Management concurred with the recommendation and stated that if the focus of our recommendation is on FFRDC designation and not the validation of a laboratory's mission, the Procurement Executive can require that this subject be addressed by M\&O contract extend/compete boards and an appropriate statement be included in the files.

The RESULTS OF INSPECTION section of this report beginning on page 7 provides a more detailed discussion of our findings and recommendations.

\section{BACKGROUND}

\section{Establishment of First FFRDCs}

According to the OFPP policy letter, a Government-wide policy for the identification and maintenance of a master listing of FFRDCs was established by a memorandum from the Chairman of the Federal Council for Science and Technology on November 1, 1967.

FFRDCs first came into existence during World War I to meet special research needs that federal and private sector 
facilities were unable to provide. The first FFRDC, or Federal Contract Research Center as it was previously called, was established by the Department of Defense during and immediately following world war II, to obtain the top scientific and technological talent that the Department of Defense "was otherwise unable to attract". Since that time, the Department of Defense and other Federal agencies have established and sponsored FFRDCs to meet a variety of research needs.

\section{The Commission Supported Continued Use of FFRDCs}

At the suggestion of Congress, the Commission on Government Procurement evaluated the "special relationships" of FFRDCs to their agency sponsors. The Commission established a Research and Development study Group to conduct a review of federal contracting for research and technology development. Based, in part, on the study group's report, the Commission issued a report on government. procurement in 1972 which included a recommendation to:

"[c]ontinue the option to organize and use FFRDCs to satisfy needs that cannot be satisfied effectively by other organizational resources. Any proposal for a new FFRDC should be reviewed and approved by the agency head and special attention should be given to the method of termination, including ownership of assets, when the need for the FFRDC no longer exists. Existing FFRDCs should be evaluated by the agency head periodically (perhaps every three years) for continued need."

\section{OFPP Issued FFRDC POIICY}

On April 4, 1984, OFPP issued government-wide policies on the establishment, use, periodic review and termination of FFRDCs. The OFPP policy and procedures have been implemented in the FAR-Subpart 35.017.

According to these policies, FFRDCs are established to meet some special research or development need which, at the time, cannot be met as effectively by existing in-house or contractor resources. These policies require agencies to conduct a comprehensive review of the use and need for each FFRDC F-ior to establishing or renewing them. These policies also require the National science Foundation to maintain a master listing of FFRDCs. 
OFPP also required that each agency review its pre-existing FFRDCs for compliance with its FFRDC policies by september 30 , 1984. Each agency was required to develop a schedule to bring their FFRDCs into compliance with the policies no later than the next renewal date of the FFRDC or five years from the date the policies were issued, whichever was sooner. Subsequent to the policy letter, DOE continued to operate and manage the 20 pre-existing laboratories, designated as FFRDCs, in accordance with its M\&O procedures.

\section{Senate Report Called for Increased Controls Over FFRDCs}

On July 8, 1992, the Senate Subcommittee on Oversight of Government Management of the Committee on Governmental Affairs published a report entitled "Inadequate Federal Oversight of Federally Funded Research and Development Centers". The report was based on a government-wide survey of FFRDCs in 1991 to obtain a better understanding of the procedures used to ensure appropriate use of federal funds.

While the senate subcommittee report supported the continued agency use of FFRDCs, it revealed problems related to "an inadequate, inconsistent patchwork of federal cost, accounting and auditing controls at FFRDCs." The report also detailed the need for strengthened federal controls over FFRDCs spending and provided ten recommendations to strengthen federal oversight of FFRDCs. These recommendations included requiring stronger cost controls in FFRDC operating contracts; increasing oversight of indirect costs; requiring federal guidelines and annual justifications of management fee requests; revamping auditing practices including assessing DOE's practice of relying on audits performed by its FFRDCs; increasing competition; evaluating arrangements which permit shell corporations to operate FFRDCs and multiple FFRDCs to function at a single site; and requiring budget line items for each FFRDC facility.

\section{OFPP Called for an Evaluation of the Need for FFRDCs}

Following the issuance of the senate subcommittee's July 8 , 1992 report, in a september 16, 1992 memorandum to the DOE Inspector General, OFPP officials stated that:

"We belicve that FFRDC contracts are intended to be long-term in nature. However, the [OFPP] policy requires that agencies conduct analyses prior to renewing FFRDCs to determine whether the unique FFRDC relationship is still 
needed. The analyses should address whether the marketplace has changed to the point where competition should be sought. They should also evaluate past performance and any future changes to the FFRDC's mission."

\section{Designation of FFRDCS in DOE}

At the time OFPP policy was established in 1984, DOE had 20 laboratories listed by OFPP as pre-existing FFRDCs. Since the OFPP policy became effective in 1984, DOE has established two new FFRDCs-the Continuous Electron Beam Accelerator Facility and the Inhalation Toxicology Research Institute. Thus, at one time the Department had as many as 22 FFRDCs. Department officials decided to discontinue three FFRDCs-the Hanford Engineering Development Jaboratory, the Knolls Atomic Power Laboratory and the Bettis Atomic Power Laboratory, and notified the National Science Fourdation to this effect in October and December 1992 .

DOE now has a total of 19 FFRDCs (see Appendix A), and has entered into $19 \mathrm{M} \& O$ contracts with corporations, universities and non-profit organizations to manage and operate its FFRDCs and the work performed at these laboratories. The M\&O contractors that operate DOE's FFRDCs employ approximately 63,000 personnel. DOE has provided funding of at least $\$ 6.5$ bililion at these laboratories in fiscal year 1992 .

The following section provides a more detailed discussion of DOE's* position regarding OFPP FFRDC policy and procedures; and our findings regarding DOE's compliance with OFPP's policy and procedures for renewing and establishing FFRDCs.

\section{RESULTS OF INSPECTION}

\section{DOE Position on FFRDC Policy and Procedures}

During the development of OFPP policy and procedures, in the early 1980's, DOE officials advised OFPP officials that DOE had no interest in designating its laboratories as FFRDCs. The FFRDC related files in DOE's Office of Procurement Policy show that over the years prior to the issuance of the 1984 OFPP policy letter that listed 20 DOE laboratories as FFRDCs, DOE had continued to actively oppose such issuance of a single FFRDC policy as "wholly inappropriate".

Page 7


According to a 1980 DOE point paper on FFRDCs, DOE offj.cials had questioned the National Science Foundation regarding the advantages of the Department's laboratories being listed as FFRDCs in the annual National Science Foundation report to Congress. The point paper included a statement that the National science Foundation responded that only the perception of prestige would accrue to the sponsored organization and that they know of no tangible benefit as a result of such a listing. In order t: evaluate the merits of designating its research laboratories as. FFRDCs, the advantages and disadvantages of an FFRDC to a sponsoring agency were listed in the point paper (see Appendix B).

In a May 20, 1981 internal memorandum, a DOE procurement official wrote thai:

"...a presentation was given to OFPP on DOE's management and use of FFRDC's. It was pointed out to OFPP that DOE did not have any FFRDC's with perhaps the exception of SERI [Solar Energy Research Institute]. DOE employs contractors to run facilities, some of these facilities are laboratories and happen to be listed in the NSF [National Science Foundation] publication as FFRDC's because the preponderance of their work is research and development. DOE does not assign work on the basis of research or development or production, it assigns work on capability and need. All of DOE's operating contractors are treated as a class and it is their position as managers of facilities that dictates the management controls and not the work assigned...."

According to an interagency task force on FFRDCs, the inclusion of DOE's national laboratories with the Department of Defense's Federal Contract Research Centers in the National science Foundation's "Federal Funds for Research, Development and other Scientific Activities" report to Congress had invited OFPP's "erroneous" conclusion that FFRDCs are much the same and could be similarly controlled by a single directive which recognizes no inherent difference among FFRDCs. On March 10, 1982, DOE requested that the National Science Foundation formally amend its reporting categorization to provide a subset breakdown which recognized the inherent differences which existed among the FFRDCs.

Subsequently, an interagency task group was formed in 1982. The task group members were appointed by the Departinent of Defense, the Department of Energy, the National Aeronautic and space Administration, the Department of Health and Human Services, the office of Management and Budget, and the National science 
Foundation. The task group reached a general consensus to subdivide the National Science Foldndation's FFRDC list into four distinct sub-groups. According to a task group status report, the sub-groupings achieved the task group's and DOE's purposes of (1) recognizing that all FFRDCs are not the same and hence, may not need to be treated the same, and (2) separating DOE's national laboratories from the Department of Defense's Federal Contract Research Centers. The sub-grouping of FFRDCs was incorporated into the policy letter in the April 11, 1984 Federal Register.

Following the issuance of the OFPP policy letter in 1984, the DOE Director of the Procurement and Assistance Management Directorate stated in a letter to the Administrator of OFPP that the research and development centers listed in the OFPP policy letter are the DOE's national laboratories and that:

"[DOE] manages these facilities through the use of a management and operating contract which allows the requirements of law, regulation and departmental policies to be applied to these contractors. The few facilities that are labeled as Federally Funded Research and Development Centers (FFRDC's) are not managed differently than our other facilities... [and the facilities' designated as FFRDCs] mission and output is monitored by the office of science and Technology Policy and budgets approved by Congress."

The letter further stated that, during the drafting of the OFPP policy letter, DOE had affirmed that the requirements of the OFPP FFRDC policy would be fulfilled by existing DOE M\&O contract policies. The DOE policies cited by the letter are now known as: 1) "Institutional Planning by Multiprogram Laboratories" (DOE Order 5000.1B), which establishes the DOE policies regarding institutional planning by its multiprogram laboratories; 2) "Operating and Onsite Service Contract Extend or Compete Decisions" (DOE Order 4210.5A), which establishes procedures for the coordination and review of recommendations to extend or solicit competitive proposals for M\&O contracts; 3 ) "Site Development Planning" (DOE Order 4320.1B), which establishes policies and assigns responsibilities and authorities for the planning and development of DOE sites; and 4) "Non-Department of Energy Funded Work (Work for Others)" (DOE Order 4300.2B), which establishes DOE policy, procedures, and responsibilities for authorizing and administering non-DOE funded work. We noted that the 1984 OFPP policy letter stated that FFRDC policy will be implemented in the FAR to be compatible with FAR Subpart 17.6 "Management and Operating Contracts" 


\section{DOE's Compliance with OFPP Renewal Procedures for FFRDCS}

\section{DOE M\&O Contract Extend/Compete Procedures}

As discussed in the previous section of this report, DOE officials had determined that it would use its M\&O contract extend/compete procedures to satisfy the OFPP requirements for renewal of FFRDCs. These procedures are based on FAR subpart 17.605, "Award, renewal, and extension." (see Appendix C), which states that an $M \& O$ contract should be reviewed by a contracting officer at least every five years to determine if meaningful improvement in performance or cost may reasonably be achieved. The regulation further states that extension of an M\&O contract must be authorized by the head of an agency. In addition, FAR Subpart 17.605 and the Department of Energy Acquisition Regulation (DEAR), section 970.0001, "Renewal of management and operating contracts." (see Appendix D), state that replacement of an incumbent contractor is usually based largely upon expectation of meaningful improvement in performance or cost and that the contracting officer should consider the following factors when reviewing contractor performance:

(1) The contractor's overall performance.

(2) The potential impact of a change in contractors on program needs.

(3) Whether it is likely that qualified offerors will compete for the contract.

Consistent with the FAR and DEAR, DOE established Order 4210.5A, "Operating and Onsite Service Contract Extend or Compete Decisions", which includes procedures for the coordination and review of recommendations to extend or solicit competitive proposals for its M\&O contracts.

The Order states that, heads of contracting activities should submit recommendations for extension or competition of M\&O contracts 18 months before the expiration of the current contract period. This 18 month period is supposed to provide DOE the necessary time to review the contract requirements and to open the contract for competition when appropriate. The Order is intended to ensure appropriate coordination and review among field and Headquarters user activicies and staff offices before the submission of a decision for renewal is forwarded to the secretary, Deputy secretary, or Under secretary for 
approval. According to the Order, an Extend/Compete Review Board is set up to coordinate and review recommendations to extend or solicit competitive proposals for M\&O contracts.

The Review Board is chaired by the Director of the Office of Clearance and Support. The Review Board usually includes members from the responsible Program Office, General Counsel and Controller offices. The agenda for the review generally includes a presentation of background and recommendation by the representative of the head of the contracting activity and a presentation by the cognizant Headquarters program office(s) on program plans affecting the extend/compete decision. In accordance with DOE Order 4210.5A, the Review Board makes their recommendations based on the following criteria:

(1) Current contractor's overall performance.

(2) Potential effects of a change of contractors.

(3) Availability of competition for contract.

(4) Appropriateness of the scope of work.

(5) Appropriateness of the period of performance.

The Revin Board's decision also includes a discussion of other pertinenc issues such as whether it is likely that competition would provide meaningful improvement in the Government's position in terms of performance or cost; whether a change in contractor would be contrary to the best interest of the Department; and whether the agreement should be extended for five years using an M\&O contract.

\section{OFPP FFRDC Renewal Procedures}

OFPP FFRDC policy states that prior to renewal of a sponsoring agreement with an FFRDC, agencies shall conduct a comprehensive review of the use and need for each FFRDC that they sponsor (see Appendix E). The OFPP policy letter also states that agencies shall conduct periodic reviews of their FFRDCs at least every five years. The results of the periodic reviews shall be documented and include:

(1) An examination of the agency's special technical needs and mission requirements.

(2) Alternative sources to meet the agency's needs. 
(3) An assessment of the efficiency and effectiveness of the FFRDC in meeting the agency's needs.

(4) An assessment of the adequacy of the FFRDC management in assuring a cost effective operation.

(5) Compliance with the OFPP policy section.

The OFPP policy, in essence, requires that agencies, prior to renewing an FFRDC, determine that the criteria for establishing an FFRDC continues to be satisfied and that the sponsoring agreement is in compliance with OFPP policy. The OFPP policy letter further states that when a sponsor's need for the FFRDC no longer exists, the sponsorship may be transferred to one or more Government agencies, if appropriately justified.

Dtherwise, the FFRDC shall be phased out, the assets disposed of and all liabilities settled according to the terms and conditions of the sponsoring agreement.

Differences between DOE Procedures and FFRDC Renewal Requirements

We found that DOE officials do not maintain any "FFRDC" renewal files. Instead, DOE officials maintain M\&O contract extend/compete review files that include the contract renewal decisions for the operation of the laboratories designated as FFRDC's. Based on our limited review, we found that DOE's M\&O extend/compete procedures are similar to the OFPP renewal procedures in that: 1) they require renewal at least every five years; 2) they include a review of the agency's special technical needs; and 3 ) they include a review of the performance of the M\&O contractor that manages DOE's FFRDC.

DOE's M\&O contract extend/compete procedures, however, differ from OFPP renewal procedures in that they do not specifically require that Departmental officials 1) determine that the criteria for establishing an FFRDC continue to be satisfied and that the sponsoring agreement (M\&O contract) complies with OFPP policy; 2) look at whether alternative sources exist to meet the technical needs of the DOE; and 3 ) review whether FFRDC operations have been cost effective.

The following is a more detajled discussion on how DOE uses its M\&O extend/compete procedures to satisfy the OFPP FFRDC renewal criteria. 


\section{DOE's Review of Its Special Technical Needs}

In accordance with DOE Order $4210.5 \mathrm{~A}$, "Operating and Onsite Service Contract Extend or Compete Decisions", the Review Board evaluates the appropri eness of the scope of work for the M\&O contractor being reviewed. In addition, the Review Board meeting includes $a$ presentation of background and recommendation by the representetive of the head of the contracting activity and a presentation by the cognizant Headquarters program office(s) on pregram plans affecting the extend/compete decision.

During the most recent extend/compete reviews, DOE officials decided to non-competitively extend 18 of the M\&O contracts that manage DOE's FFRDCs. We reviewed all 18 Review Board

recommendations and found that they included a discussion of how each laboratory would contribute to the DOE mission. In addition, nine of the FFRDCs are multiprogram laboratories and an institutional plan is prepared and updated annually for each of these laboratories, in accordance with DOE Order 5000.1B, "Institutional Planning by Multiprogram Laboratories". The institutional plan includes an overview of a laboratory's mission, 20-year strategic plan, scientific initiatives, research programs, technology transfer, educational support and environment, safety and health activities. The institutional planning requirement does not apply to the other DOE FFRDCs.

\section{DOE's Review of Performance}

In accordance with DOE Order 4210.5A, "Operating and Onsite Service Contract Extend or Compete Decisions", the Review Board addresses the current contractor's performance in managing the FFRDC. The current contractor's performance is evaluated by the cognizant field office and the evaluation is forwarded to the Review Board for consideration in the extend/compete review process.

\section{Alternative Sources to Meet Agency's Needs}

In accordance with DOE Order 4210.5A, "Operating and Onsite Service Contract Extend or Compete Decisions", the Review Board evaluates the potential effects of a change of current contractor and the availability of competition for the contract. However, we did not find that the extend/compete process 
required the evaluation of alternative sources to meet the Department's needs or a determination of whether the criteria for establishing the FFRDC continued to be satisfied.

In response to this finding, the Associate Director, Procurement, Assistance and Property stated that:

"The establishment of an FFRDC is a consideration of whether its assigned mission can be effectively met by existing resources and capabilities. These are long-term national goals and programs not readily existent in the private and nonprofit sectors. The development of budgets of longer institutional plans which cover periods of 5 years or longer are part of the laboratory management process and are given to the Congress and others. We would submit that the system is a consistent and ongoing validation process of the justification of the continued need for a specific laboratory. The OIG seems to be stating there should be a resolution of the mission and need at each laboratory at the time of each contract renewal. We believe the ongoing Managerial process validates the need for the facility and the extend-compete process decides who are to be the operators. Therefore, it would appear to us that existing Department procedures are in fact an assessment of whether an FFRDC/Laboratory mission is still necessary."

When we reviewed the M\&O contract extend/compete files, we did not find documentation that the Review Board surveyed to determine if there were other alternative sources available to accomplish the Department's needs. Nor did we find documentation of a determination that the criteria for establishing specific FFRDCs continued to be satisfied and that the FFRDC sponsoring agreement (M\&O contract) complied with OFPP policy. Also the institutional planning process only covers nine of the Department's 19 FFRDCs, and even then it does not appear to address the OFPP requirement that agencies evaluate the continuing need for an FFRDC.

In responding to our finding Office of Energy Research officials stated that they had a different interpretation of the term "alternative sources." The Director, Office of Management, office of Energy Research stated that:

"We disagree that an Office of Federal Procurement Policy (OFPP) Policy Letter requires a periodic evaluation of alternatives to contracting with a Federally Funded Research and Development Center (FFRDC) for meeting an agency's needs. The Policy Letter requires periodic review of 
'alternative sources to meet the agency's needs.' Assuming that the scope of work assigned to the FFRDC, which

originally required the special relationship contemplated by the FFRDC contract, has not changed, that work continues to be appropriately assigned to the FFRDC. In our opinion, what is required to be reviewed is the contractor that operates the FFRDC.

Within the procurement community the terms 'sources sought' (as advertised in the Commerce Business Daily), the Source Evaluation Board, and 'source selection procedures, ' all refer to the contracting organization, not the type of award instrument."

An OFPP official stated that the term "alternative sources" is in reference to the FFRDC, but that consideration of alternative contractors to operate FFRDCs may be viewed as meeting OFPP policy in the future.

\section{Record of Providing Cost Effective Operation}

DEAR section 970.1508, "Price negotiation.", states that the M\&O contract prices (fee) and DOE obligations to support contract performance is governed by the level of activity authorized and the amounts of funds appropriated for DOE approved programs by specific program legislation; congressional budget and reporting limitations; the amount of funds apportioned to DOE; the amount of obligation authority allotted to program officials; the Approved Funding Program limitations; and the amount of funds actually available to the DOE operating activities as determined in accordance with applicable financial regulations and directives.

DOE, in association with the M\&O contractor, establishes an annual operating and capital expenditure budget for performance at a prescribed level of activity, as established by DOE, to fulfill its mission requirements. Contractor obligations, commitments and expenditures are limited to specific funding levels established by DOE and are controlled through the issuance of Approved Funding Programs to the contractor. In our review of the extend/compete files, we found that the "Justification for Other Than Full and Open Competition" documents for the extended M\&O contracts contain a statement similar to the following:

The DOE budget process and the DOE oversight of performance provides adequate controls to assure that expenditures 
(costs) to support the required levels of authorized activity are fair and reasonable.

Based on our limited review of the DOE's M\&O contract extend/compete review files in Headquarters, we found that cost effectiveness of contractors' operations is not always reviewed during contract renewal. We also found that the Department made a determination in 1985 that its M\&O contractors, including those that manage DOE's FFRDCs, do not have to submit certified cost or pricing data prior to the award, extension or

modification of their contracts as would be normally required by the Competition in Contracting Act of 1984 , even when the FFRDC contract is being competed. Departmental officials stated in their 1985 determination that cost or pricing is not required because DOE controls its cost through the budget.

We further noted a special exemption had been granted to the Sandia National Laboratories' contractor, AT\&T Technologies, Incorporated (formerly Western Electric Company, Incorporated). The Sandia National Laboratories' contract originated in 1949 and a Presidential Exemption has been granted to AT\&T since 1964, in accordance with the Atomic Energy Act of 1954, so that indemnification of the contract will not be subjected to the availability of appropriated funds. AT\&T requested and received a Presidential Exemption for their latest contract renewal in 1988. However, AT\&T has decided not to continue as the contractor at Sandia when its contract expires in 1993.

Despite these findings, we believe that DOE officials have begun to take steps that recognize the importance of ensuring that contractors' operations are cost effective. For example, in response to a recommendation in our 1990 report entitled "General Management Inspection of the Department of Energy's San Francisco Operations Office", the Department established procedures to review the indirect costs of its M\&O contractors in the field budget process. Also, In July 1991, the Department established an Accountability Rule for its for-profit M\&O contractors, which is designed to improve the accountability and performance of its for-profit contractors. Furthermore, in its 1992 Federal Managers' Financial Integrity Act letter to the former President, the Department stated that the business management practices of the Department and its contractors need improvement to ensure programs and projects are completed within costs and established schedules. Finally, DOE incorporated the requirements of its work authorization control system in $17 \mathrm{MaO}$ contracts, including two M\&O contracts that manage FFRDCs, as of May 1993. Finally, the secretary stated in her testimony before the Subcomittee on Oversight and Investigations of the 
Committee on Energy and Commerce, on May 26, 1993, that DOE is not adequately in control of its contractors and as a result the contractors are not sufficiently accountable to the Department. The secretary announced in her testimony initiatives to improve contract management practices, to include efforts to increase cost control measures.

\section{DOE Sole-Source Renegotiation Practice and Authority}

We reviewed the DOE's M\&O contract extend/compete review files in Headquarters for DOE's 19 FFRDCs. Uur review showed that DOE does not consider whether to renew its FFRDCs, but instead conducts reviews to determine whether to extend or compete the M\&O contracts to operate the FFRDCs. 18 of the 19 M\&O contracts to operate the DOE FFRDCs were non-competitively extended during their most recent extend/compete reviews. In the one exception, where the contract was competed, the contractor had decided not to continue with the M\&O contract. Of the 18 contracts most recently extended, six were established in the 1940's, three in the 1950's, five in the 1960's, two in the 1970's and two in the 1980 's. Ten of DOE's FFRDCs have been managed by the same contractors for over 40 years.

The one FFRDC whose M\&O contract was recently competed in 1989, had previously been operated by the same contractor since 1952 . The previous contract had been extended more than seven times. In 1987, the previous contractor notified DOE that it would not seek to renew its contract to manage the laboratory when it expired. As a result, DOE entered into a competitively awarded contract with another contractor in 1989.

The sole-source renegotiation justification authority used by the Department to non-competitively extend 18 of these M\&O contracts was stated in the "Justification for other Than Full and Open Competition" in a statement similar to the following:

The authority to noncompetitively extend M\&O contracts necessary to the performance of DOE's energy research and development program is found in the Atomic Energy Acts of 1946 and 1954, as amended, and the Federal Property. \& Administration Act of 1949, including the amendments thereto by Public Law 98-369 [Competition in Contracting Act of 1984]; specifically section 303 (C)(3)(B) which states that an executive agency may use procedures other than competitive procedures only when "... it is necessary to award the contract to a particular source or sources, in order...(B) to establish or maintain an essential 
engineering, research or development capability to be provided by an educational or other nonprofit institution or a federally funded research and development center."

From the above discussion, DOE does not need the FFRDC designation to extend its M\&O contracts that operate its FFRDCs. FAR Subpart 17.6, "Management and Operating Contracts" provides that authority. This subpart states, in part, that agencies may use its statutory authority to enter into or renew any M\&O contract. In accordance with FAR Subpart 17.602(a), "Policy.", renewal of an M\&O contract must be authorized by the head of an agency. DEAR section 970.0000, "Scope of part.", states, in part, that use of an M\&O contract mus: be authorized by the Secretary, Deputy Secretary or Under Secretary. In accordance with regulations, an "Authorization for Renewal of a Management and Operating Contract" was prepared and signed by either the Secretary, Deputy Secretary or Under Secretary for each of the 18 extended M\&O contracts discussed above. We also noted that DOE does not formally document its decisions to extend the designation of its FFRDCs.

\section{Recommendation}

We recommend that the Acting Deputy Assistant Secretary for Procurement and Assistance Management require written documentation of the decision to continue the FFRDC designation when an M\&O contract to operate an FFRDC laboratory is extended or awarded.

The Acting Deputy Assistant Secretary for Procurement and Assistance Management concurred with the recommendation and stated that if the focus of our recommendation is on FFRDC designation and not the validation of a laboratory's mission, the Procurement Executive can require that this subject be addressed by M\&O contract extend/compete boards and an appropriate statement be included in the files.

\section{DOE's Compliance with OFPP FFRDC Establishment Procedures}

The OFPP's 1984 policy letter states that when FFRDCs are established, long-term Government relationships are encouraged in order to provide the continuity that will attract high quality personnel to the FFRDC. The OFPP Policy letter also states that in establishing an FFRDC the sponsoring agency shall ensure that: 
(1) Existing alternative sources for satisfying agency requirements cannot effectively meet the special research or development needs.

(2) At least three notices are placed over a 90-day period in the Commerce Business Daily and the Federal Register indicating the agency's intention to sponsor an FFRDC and the scope and nature of the effort to be performed by an FFRDC.

(3) Sufficient government expertise is available to adequately and objectively evaluate the work to be performed by an FFRDC.

(4) Controls are established to ensure that the costs of the services being provided to the government are reasonable.

(5) The purpose, mission, and general scope of effort of the FFRDC is stated clearly enough to enable differentiation between work that should be performed by an FFRDC and that which should be performed by a non-FFRDC.

OFPP policy also states, in part, that in establishing an FFRDC, the sponsoring agency should ensure that 1) the office of Science and Technology Policy, is notified; 2 ) the FFRDC is operated, managed, or administered by an autonomous organization or as an identifiably separate operating unit of a parent organization; and 3 ) quantity production or manufacturing is not performed unless authorized by legislation.

We found that DOE notified the office of Science and Technology Policy when it established new FFRDCs; and that DOE FFRDCs are operated or managed by universities, or consortium of universities, other nonprofit organization, an autonomous industrial firm, or separate operating unit of a company. Based on the limited scope of this inspection, we did not determine if quantity production or manufacturing is performed at DOE's FFRDCs.

We found that DOE followed OFPP's policy of notification in the Commerce Business Daily and the Federal Register prior to establishing two new FFRDCs since 1984, but did not necessarily comply with OFPP requirements to ensure that alternatives to an FFRDC did not exist that could meet DOE's technical needs. We also found that because DOE controls its FFRDC's cost through the budget process, it has not necessarily implemented procedures to ensure that FFRDCs are operated in a cost 
effective manner as required by the OFPP policy. Furthermore, DOE may not have sufficient government expertise and staff available to adequately and objectively evaluate the work to be performed by its FFRDCs which is a requirement of OFPP policy. In its 1992 Federal Managers' Financial Integrity Act letter to the former president, DOE stated that it needed to recruit qualified project managers for its projects. Following is a summary discussion of the now FFRDCs established by DOE since 1984.

\section{New DOE FFRDCS}

Since the OFPP policy letter became effective in 1984 , the Department has established two new FFRDCs-the Continuous Electron Beam Accelerator Facility, and the Inhalation Toxicology Research Institute on June 17, 1987 and February 6, 1989, respectively.

\section{Continuous Electron Beam Accelerator Facility}

The Nuclear Science Advisory Committee, established by DOE and the National Science Foundation in 1977 to identify technical needs in nuclear physics, issued a report in April 1982, expressing the need for a new accelerator that would provide a continuous beam of electrons in the one to two billion electron volt energy range. By January 1983, DOE had received five unsolicited proposals for such a facility. DOE requested the Nuclear Science Advisory Committee to perform a review and recommend the best proposal. The Nuclear Science Advisory Committee conducted its review of the five proposals from mid-January through April 1983. On April 29, 1983, after reviewing and evaluating all five proposals, the Nuclear science Advisory Committee recommended to DOE that Southeastern Universities Research Association, should manage and operate the Continuous Electron Beam Accelerator Facility.

However, according to a General Accounting office (GAO) report, the establishment of the Continuous Electron Beam Accelerator Facility may not have considered all alternative sources. In an April 1986 GAO report entitled "DOE Should Provide More Control in Its Accelerator Selection Process", GAO officials stated that DOE selected the Continuous Electron Beam Accelerator Facility design based on the Nuclear Science Advisory Committee's recommeridation when at least ol. b better design was available and another technology was nearing completion. GAO officials also stated in the report that it was DOE's responsibility to ensire 
that all applicable technologies should have been identified and evaluated, and that the best technology was selected. The GAO report went on to say that in the case of the Continuous Electron Beam Accelerator Facility selection, the use of unsolicited proposals by DOE did not identify all applicable technologies that were available from the nuclear physics community.

In response to the GAO report, DOE officials stated that funding nuclear physics accelerator projects using the unsolicited proposal inspires innovative designs and heightens competition within the nuclear physics community.

In accordance with the OFPP FFRDC establishment requirements, DOE had published the notices of intent to establish the Continuous Electron Beam Accelerator Facility as an FFRDC in the Commerce Business Daily on March 18, April 14, and May 14, 1987, and in the Federal Register on March 12, April 9, and May 12, 1987.

\section{Inhalation Toxicology Research Institute}

The Inhalation Toxicology Research Institute has served DOE continuously since 1960 in the biological effects of exposure to airborne toxicants. While not formally designated as an FFRDC by the 1984 OFPP policy letter, the Inhalation Toxicology Research Institute was designated as an FFRDC on February 6, 1989. In accordance with the OFPP's FFRDC establishment requirements, notices of intent to establish the Inhalation Toxicology Research Institute as an FFRDC were published in the Commerce Business Daily on July 25, August 24, and December 14, 1988 , and in the Federal Register on July 20, August 31 and September 9, 1988 .

The Office of Energy Research received several public comments based on the published notices. The Office of the General Counsel reviewed each public comment and the office of Energy Research responses, and concurred that no adverse comments remained outstanding which would have prevented the designation of the Inhalation Toxicology Research Institute as an FFRDC.

\section{Sponsoring Agreements}

The policy letter staces that a contract is the generally preferred instrument under which an FFRDC accomplishes effort for its sponsor(s) and that the specific content of a sponsoring 
agreement will vary depending on the situation. The policy letter further states that the following mandatory requirements must be addressed in either a contract, a sponsoring agreement or sponsoring agency's policies and procedures:

(1) A delineation of the purpose for the FFRDC with a description of its mission, general scope of effort envisioned to be performed, and the role tine FFRDC is to have in the accomplishment of the sponsoring agency's mission.

(2) Provisions for the orderly termination or nonrenewal of the agreement, disposal of assets and settlement of liabilities. The term of the sponsoring agreement will not exceed five years but can be renewed, as a result of periodic review, in not to exceed five year increments.

(3) Prohibition against competing with any non-FFRDC in response to a procurement request.

(4) Whether or not the FFRDC may accept work from other than the sponsor $(s)$.

According to OFPP policy, the term of a sponsoring agreement cannot exceed five years, but can be renewed in increments not to exceed five years.

\section{DOE Sponsoring Agreements}

Currently, DOE has $19 \mathrm{M} \& O$ contracts with corporations, universities and non-profit organizations as the sponsoring agreements to manage and operate its laboratories designated as FFRDCs. Seventeen of these 19 M\&O contractor operated laboratories were listed as FFRDCs by the National science Foundation based on the 1984 OFPP policy letter.

From our review of the M\&O contract extend/compete review files at Headquarters, we determined that the terms of the sponsoring agreements for all 19 FFRDCs do not exceed five years, and that the M\&O contracts have been periodically reviewed in increments not exceeding five years in accordance with DOE Order 4210.5A, "Operating and Onsite Service Contract Extend or Compete Decisions".

Although we did not look at the 19 DOE "sponsoring agreements" (M\&O contracts), we did review the DEAR and found that it includes $M \& O$ contract clauses that address the OFPP policies for 
sponsoring agreements. Specifically, DEAR section 970.49, "Termination of Contracts", states that all M\&O contracts shall contain appropriate termination provisions. DEAR section 970.52, "Contract Clauses for M\&O Contracts", sets forth provisions for the orderly termination of a contract and a clear description of work being undertaken in the statement of work. The provisions for the use of DOE facilities for work for others are set forth in DEAR section 970.70, "Use of DOE Facilitics for Work for Others". Furthermore, the DOE Order 4300.2B, "Non-Department of Energy Funded Work (Work for Others)", states, in part, that work for non-DOE entities can only be undertaken when the responsible contracting officer has determined and certified in writing that the work would not place a DOE facility in direct competition with the domestic private or public sectors.

\section{Three FFRDCs Were Discontinued and One is Questioned}

The designation of three of DOE's FFRDCs was discontinued in 1992. The three FFRDCs were the Hanford Engineering Development Laboratory, the Bettis and Knolls Atomic Power Laboratories. Also, the designation of one FFRDC, which continues, was questioned by the Committee on Governmental Affairs in a letter dated April 13, 1992. The FFRDC questioned was the Savannah River Laboratory, which at one time produced nuclear weapons components. While the Laboratory had a significant research effort ongoing, this research was tied to improving plant production operations.

\section{Bettis and Knolls Atomic Power Laboratories}

In a December 1, 1992 letter, DOE requested that the National Science Foundation remove the Bettis and Knolls Atomic Power Laboratories from their FFRDC master listing. The request was approved by the Secretary in an October 27, 1992 memorandum which stated that the Bettis and Knolls Atomic Power laboratories should not have been designated as FFRDCs because the work at these laboratories goes beyond research and development to encompass the whole spectrum of engineering functions. The memorandum also stated that these are single purpose laboratories working under contract solely for the Naval Nuclear Propulsion Program, and the Director of the Naval Nuclear Propulsion Program has direct supervisory authority over these laboratories under Executive Order and Public Law. 


\section{Hanford Engineering Development Eaboratory}

In a letter addressed to the Chairman of the Committee on Governmental Affairs dated October 10, 1992, DOE Procurement officials stated that they had reviewed the work performed at the Hanford Engineering Development Laboratory and found that it does not meet the essential requirements for the FFRDC designation. The letter stated that DOE will ask the National Science Foundation to remove the Hanford Engineering Development Laboratory from the master list when it is reissued by the National Science Foundation. In an October 23, 1992 letter, Departmental officials requested that the National science Foundation remove the Hanford Engineering Development Laboratory form its list of FFRDCs.

\section{Savannah River Laboratory}

In a letter dated February 20, 1981, the Savannah River Operations Office informed the DOE Headquarters' Office of Procurement, Assistance and Program Management that the Savannah River Laboratory should not be identified as an FFRDC because its function is to provide technical support to the operations of the Savannah River Plant. The operations of the laboratory and plant at that time were covered under the contract with E. I. du Pont de Nemours and Company for the design, construction and operation of the plant, and there was no separate contract between the $E$. I. du Pont de Nemours and Company and DOE for the operation of the Savannah River Laboratory. The letter also stated that the laboratory was an integral part of the plant's overall operations, and that a comprehensive review to determine the need for continuance of the laboratory as an FFRDC would be inappropriate and inconsistent with the DOE contract with the E. I. du Pont de Nemours and Company.

However, in an October 10, 1992 letter, the DOE Director, Office of Procurement, Assistance and Program Management advised the Chairman of the Committee on Governmental Affairs that discussion is continuing on the designation of the Savannah River Laboratory as an FFRDC. In a May 1993 letter, the Secretary advised the Chairman of the Committee on Governmental Affairs of her decision to continue the Savannah River Laboratory as an FFRDC, stating that this decision would keep the laboratory in a competitive position to utilize its capabilities to address national issues concerning the environment and other activities and programs. 


\begin{tabular}{|c|c|c|c|c|c|c|c|c|}
\hline FFRDC & M8O & $\begin{array}{l}\text { ORIG } \\
\text { FFRDC } \\
\text { CONTRACT } \\
\text { AWARD } \\
\text { DATE }\end{array}$ & $\begin{array}{l}\text { DATE OF } \\
\text { LAST } \\
\text { CONTRACT } \\
\text { RENEWAL }\end{array}$ & $\begin{array}{l}\text { CONTRACT } \\
\text { EXPIRATION } \\
\text { DATE }\end{array}$ & $\begin{array}{l}\text { METHOD } \\
\text { OF MOST } \\
\text { RECENT } \\
\text { SELECTION }\end{array}$ & $\begin{array}{l}\text { FY } \\
1992 \\
\text { OBLIGATION } \\
\text { (MILLION) }\end{array}$ & $\begin{array}{l}\text { CONTRACT } \\
\text { VALUE } \\
\text { SINCE } \\
\text { INCEPTION } \\
\text { (MILLION) }\end{array}$ & $\begin{array}{l}\text { DESCRIPTION } \\
\text { OF } \\
\text { WORK }\end{array}$ \\
\hline $\begin{array}{l}\text { Ames } \\
\text { Laboratory }\end{array}$ & $\begin{array}{l}\text { Iowa State } \\
\text { University } \\
\text { of Science } \\
\text { and Technology }\end{array}$ & $05 / 01 / 43$ & $01 / 01 / 89$ & $12 / 31 / 93$ & Extended & $\$ 36$ & $\$ 660$ & $\begin{array}{l}\text { Conduct research which underlies } \\
\text { energy generating, conversion, and } \\
\text { transmission technologies and other } \\
\text { technical areas essential to } \\
\text { National interests. }\end{array}$ \\
\hline $\begin{array}{l}\text { Argonne } \\
\text { National } \\
\text { Laboratory }\end{array}$ & $\begin{array}{l}\text { University } \\
\text { of } \\
\text { Chicago }\end{array}$ & $04 / 08 / 46$ & $10 / 01 / 88$ & $09 / 30 / 93$ & Extended & 429 & 7,500 & $\begin{array}{l}\text { Conduct research and development in the } \\
\text { physical, life and environmental sciences } \\
\text { and applied research in fission reactor } \\
\text { technologies, national defense applications } \\
\text { and supporting base technologies. }\end{array}$ \\
\hline $\begin{array}{l}\text { Brookhaven } \\
\text { Nat ional } \\
\text { Laboratory }\end{array}$ & $\begin{array}{l}\text { Associated } \\
\text { Universities, } \\
\text { Incorporated }\end{array}$ & $10 / 10 / 50$ & $01 / 01 / 93$ & $12 / 31 / 97$ & Extended & 365 & 5,068 & $\begin{array}{l}\text { Conduct basic research } \\
\text { concentra: ing on the individual } \\
\text { particles of which the nucleus } \\
\text { of the atom is composed. }\end{array}$ \\
\hline $\begin{array}{l}\text { Continuous } \\
\text { Electron } \\
\text { Beam Accelerator } \\
\text { Facility } \\
\text { Laboratory }\end{array}$ & $\begin{array}{l}\text { Southeastern } \\
\text { Universities } \\
\text { Research } \\
\text { Association, } \\
\text { Incorporated }\end{array}$ & $08 / 03 / 84$ & $10 / 01 / 92$ & $09 / 30 / 97$ & Extended & 77 & 395 & $\begin{array}{l}\text { For the cont inued design, construction, } \\
\text { managewent, and operation of } \\
\text { the laboratory to support nuclear } \\
\text { physics research. }\end{array}$ \\
\hline $\begin{array}{l}\text { Engineering } \\
\text { Technology } \\
\text { Energy Center }\end{array}$ & $\begin{array}{l}\text { Rockwell } \\
\text { Internat ional } \\
\text { Corporat ion }\end{array}$ & $11 / 01 / 66$ & $10 / 01 / 88$ & $09 / 30 / 93$ & Extended & 32 & 412 & $\begin{array}{l}\text { The primary task is the testing } \\
\text { of liquid metal reactor components } \\
\text { for nuclear energy programs. }\end{array}$ \\
\hline $\begin{array}{l}\text { Fermi } \\
\text { National } \\
\text { Accelerator } \\
\text { Laboratory }\end{array}$ & $\begin{array}{l}\text { Universities } \\
\text { Research } \\
\text { Association }\end{array}$ & $01 / 05 / 6 ?$ & $01 / 01 / 92$ & $12 / 31 / 96$ & Extended & 228 & 3,438 & $\begin{array}{l}\text { Conduct basic research in high } \\
\text { energy physics, concentrating } \\
\text { on the individual particles which } \\
\text { compose the nucleus of the atom. }\end{array}$ \\
\hline $\begin{array}{l}\text { Idaho } \\
\text { National } \\
\text { Engineering } \\
\text { Laboratory }\end{array}$ & $\begin{array}{l}\text { EG\&G } \\
\text { Idaho, } \\
\text { Incorporated }\end{array}$ & $12 / 30 / 76$ & $10 / 01 / 91$ & $09 / 30 / 94$ & Extended & 509 & 4,785 & $\begin{array}{l}\text { To furnish engineering services } \\
\text { and products, principally in nuclear } \\
\text { energy and related technologies. }\end{array}$ \\
\hline $\begin{array}{l}\text { Inhalation } \\
\text { Toxicology } \\
\text { Research } \\
\text { Institute }\end{array}$ & $\begin{array}{l}\text { Lovelace Medical } \\
\text { Foundation and } \\
\text { Lovelace Biomedica } \\
\text { and Environmental } \\
\text { Research } \\
\text { Institute }\end{array}$ & $06 / 01 / 60$ & $10 / 01 / 89$ & $09 / 30 / 94$ & Extended & 19 & 240 & $\begin{array}{l}\text { Investigate the nature and } \\
\text { magnitude of human health } \\
\text { effects which might result } \\
\text { from inhaling airborne toxicants. }\end{array}$ \\
\hline $\begin{array}{l}\text { Lawrence } \\
\text { Livermore } \\
\text { National } \\
\text { Laboratory }\end{array}$ & $\begin{array}{l}\text { University } \\
\text { of } \\
\text { California }\end{array}$ & $01 / 09 / 52$ & $10 / 1 / 92$ & $9 / 30 / 97$ & Extended & 1,098 & 16,383 & $\begin{array}{l}\text { Nuclear weapons research, } \\
\text { development and testing. }\end{array}$ \\
\hline
\end{tabular}


Department of Energy's

Federally Funded Research and Development Centers

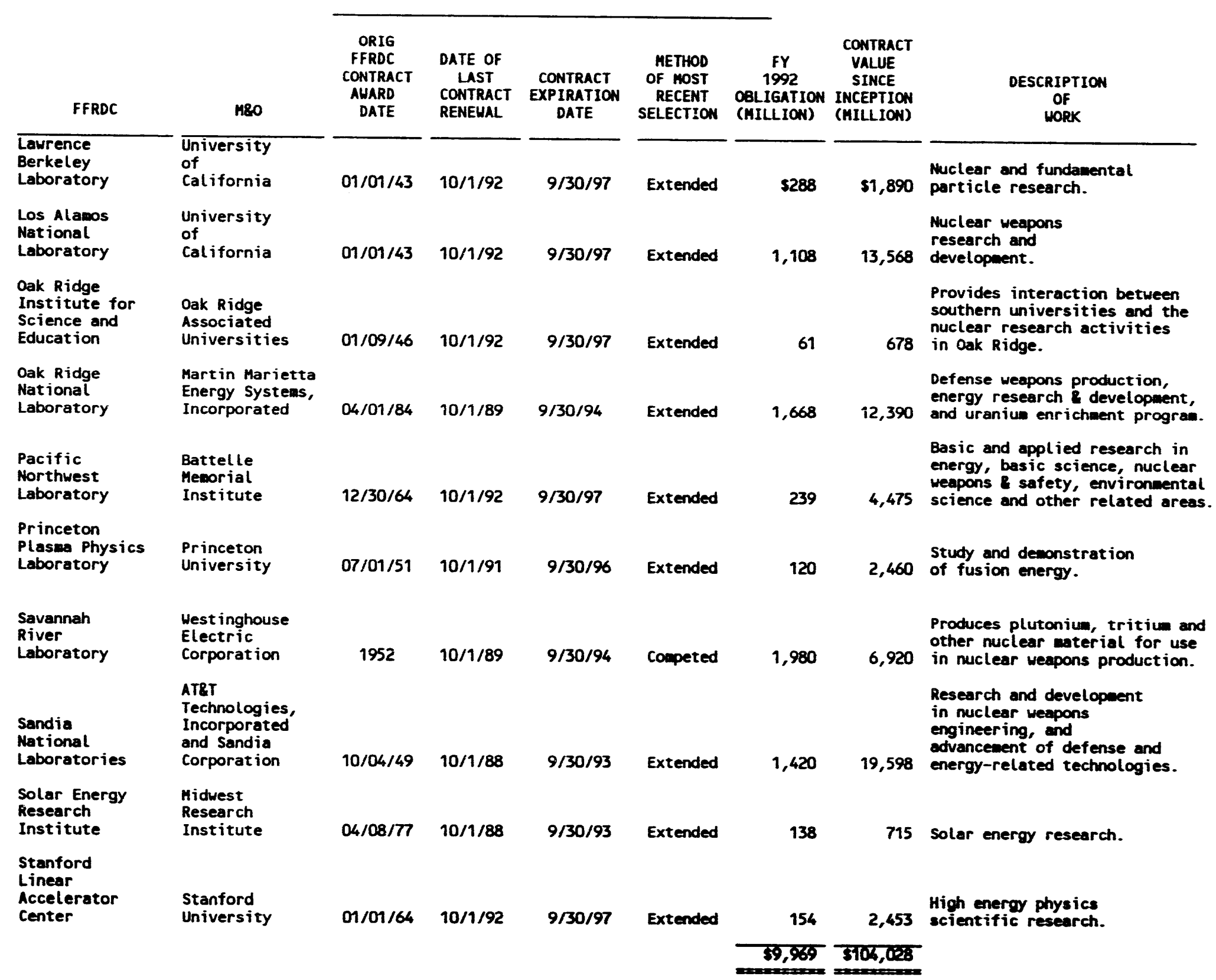




\section{Appendix B}

\section{Department of Energy Point Paper on \\ Federally Funded Research and Development Centers}

An October 29, 1980 internal procurement memorandum, "Point Paper on FFRDCs", summarized the advantages and disadvantages of an FFRDC to a sponsoring agency.

The advantages listed were as followed:

(1) Gains independent analysis due to the absence of proprietary prejudices;

(2) Gains broad base technical and professional capability in areas too new, too complex or too transient for in-house capability;

(3) Gains a "system" memory necessary for continuity in analysis;

(4) Gains an objective check on and critique of advocacy positions;

(5) Visibility by Congress and Office of Management and Budget;

(6) Assures resources and key personnel available when needed;

(7) Ease of contracting.

The disadvantages listed were as followed:

(1) Increased oversight and periodic criticism by Congress and the public;

(2) Long term commitment to a single organization;

(3) Significant investment may be required for facilities;

(4) May attract high level technical and professional talent away from Federal service;

(5) Because they tend to be the major repository of corporate memory on various projects, the sponsoring agency may be hard pressed to discontinue the relationship even in face of marginal or substandard quality work. 


\section{Appendix C}

Federal Acquisition Regulation

FAR 17.6 - Management and Operating Contracts

\section{"17.605 Award, renewal, and extension.}

(a) Effective work performance under management and operating contracts usually involves high levels of expertise and continuity of operations and personnel. Because of program requirements and the unusual (sometimes unique) nature of the work performed under management and operating contracts, the Government is often limited in its ability to effect competition or to replace a contractor. Therefore contracting officers should take extraordinary steps before award to assure themselves that the prospective contractor's technical and managerial capacity are sufficient, that organizational conflicts of interest are adequately covered, and that the contract will grant the Government broad and continuing rights to involve itself, if necessary, in technical and managerial decisionmaking concerning performance.

(b) The contracting officer shall review each management and operating contract, following agency procedures, at appropriate intervals and at least once every 5 years. The review should determine whether meaningful improvement in performance or cost might reasunably be achieved. Any extension of renewal of an operating and management contract must be authorized at a level within the agency no lower than the level at which the original contract was authorized in accordance with $17.602(a)$.

(c) Replacement of an incumbent contractor is usually based largely upon expectation of meaningful improvement in performance or cost. Therefore, when reviewing contractor performance, contracting officers should consider-

(1) The incumbent contractor's overall performance, including, specifically, technical, administrative, and cost performance;

(2) The potential impact of a change in contractors on program needs, including safety, national defense, and mobilization considerations; and

(3) Whether it is likely that qualified offerors will compete for the contract." 


\title{
Append1X D
}

\author{
Department of Energy Acquisition Regulation \\ DEAR 970 - DOE Management and Operating Contracts
}

\section{"970.0001 Renewal of management and operating contracts.}

(a) In accordance with applicable law, rules, or regulations and FAR 17.605 , competition of existing management and operating contracts will be sought whenever it appears likely that the Government's position may be meaningfully improved in terms of cost or performance, unless it is determined that to change a contractor would be contrary to the best interest of the Government. Except in those cases where the contract specifically permits the Government to bring in a replacement contractor, it in not practical in most instances to compete a management and operating contract which includes major Government-owned facilities on contractor-owned or leased sites. In such cases, the alternatives would be to extend the contract or to allow the contract to expire and, if the work is to be continued, place all or some part of the work with another contractor at a different site.

(b) The following factors, as a minimum, shall effect whether an existing management and operating contract should be completed.

(1) Overall performance of an incumbent contractor including specific consideration of the contractor's administrative, environmental, safeguards and security, safety, health, site planning, maintenance and construction, facility management, energy conservation program considerations, cost: schedule and technical performance.

(2) Potential impact of change in contractors on programmatic activities.

(3) The likelihood that qualified industrial firmis or other organizations will compete for the contract." 
Appendix E

\author{
Section 6.j. of the \\ Office of Federal Procurement Policy Letter 84-1
}

\title{
"6. Polfay.
}

j. Periodic Review. Prior to renewal of a sponsoring agreement, agencies shall conduct a comprehensive review of their use and need for each FFRDC that they sponsor. Where multiple agency sponsorship exists this review will be a coordinated interagency effort. When the funding for an FFRDC is a specific line item within the sponsoring agency's budget, the comprehensive review may be done in conjunction with the budyet process or the review may be done separately. The sponsoring agency(s) shall apprise other agencies who use the FFRDC of the scheduled review and afford them an opportunity to assume sponsorship in the event the current sponsorship is determined no longer appropriate, Final approval to continue or terminate an agency's sponsorship arrangement with a given FFRDC as a result of this review shall rest with the head of that sponsoring agency. The results of this review will be formally documented. The periodic review should include:

(1) An examination of the agency's special technical needs and mission requirements to determine if and at what level they continue to exist.

(2) Consideration of alternative sources to meet the agency's needs. Such consideration will includ. compliance with the Notice and Publication requirements of P.L. $98-72$ (15 USC $637(e)$ ) prior to renewal of the contract or Sponsoring Agreement unless otherwise exempted.

(3) An assessment of the efficiency and effectiveness of the FFRDC in meeting the agency's needs.

(4) An assessment of the adequacy if the FFRDC management in assuring a cost effective operation.

(5) A determination that the guidelines of section 6 are being satisfied." 

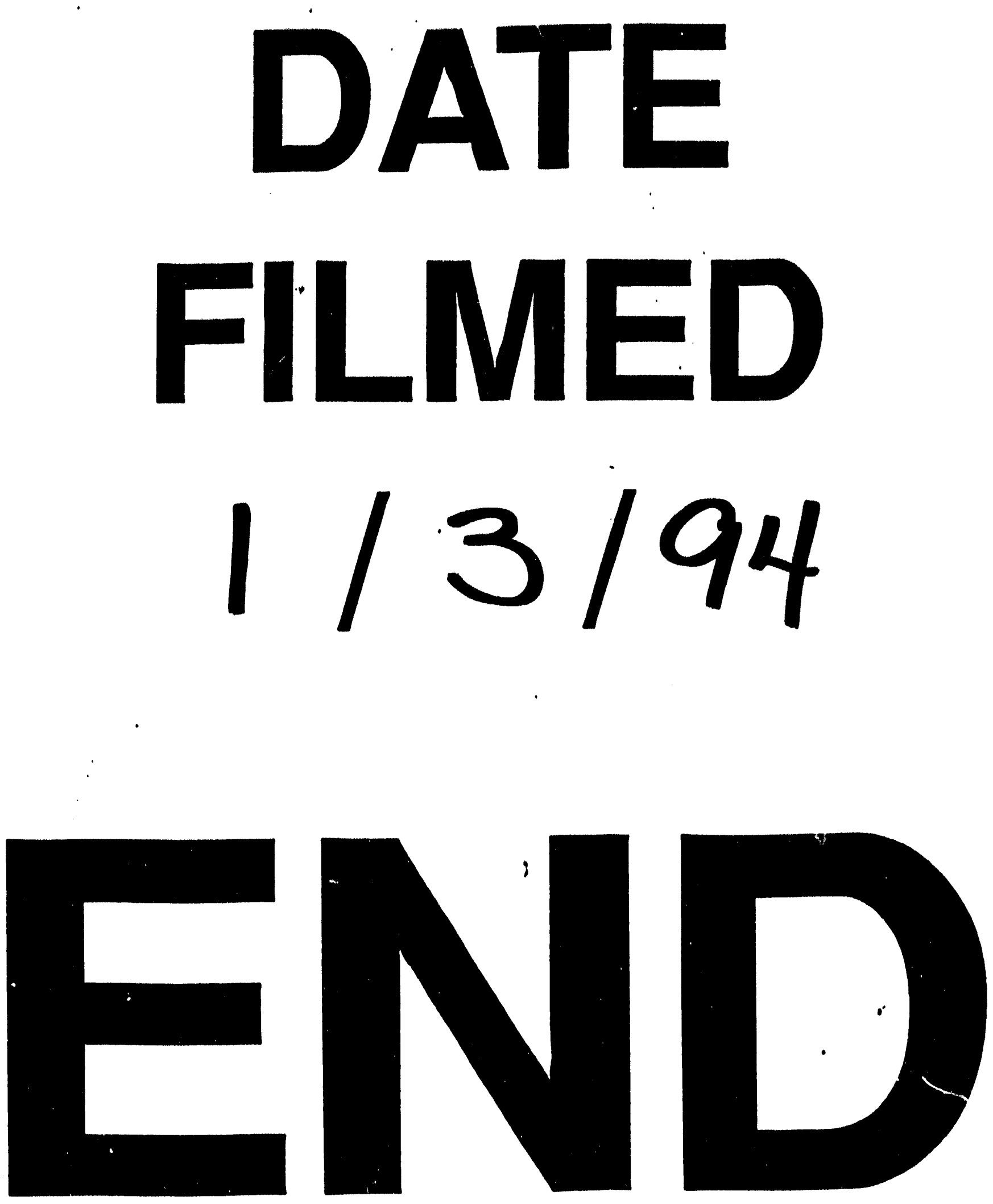


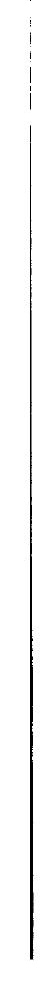

